\title{
The impact of alternative environmentally differentiated fairway dues systems in Sweden
}

\author{
Inge Vierth ${ }^{*}$ (D) and Magnus Johansson
}

\author{
* Correspondence: inge.vierth@vti.se \\ Swedish Road and Transport \\ Research Institute (VTI), Malvinas \\ väg 6 A / KTH Campus \\ Valhallavägen, Box 55685, SE-102 15 \\ Stockholm, Sweden
}

\begin{abstract}
The Swedish system for determining fairway dues at the national level is acknowledged as being unique in attempting to consider the environmental performance of vessels. Between 1998 and 2014, vessels could get a SOx discount and between 1998 and 2017 a NOx discount, both based on certificates. In 2018, the Swedish government initiated a new system comprising more environmental impacts requiring operators that want to benefit from it, to register their vessels for a score in the Clean Shipping Index (CSI). The CSI covers performance in five categories: $\mathrm{NO}_{x}, \mathrm{CO}_{2}, \mathrm{SO} / \mathrm{PM}$, Chemicals and Waste. Based on received scores, vessels can get $10 \%, 30 \%$ or $90 \%$ discount. In this paper, the short-term outcome of the new system is analysed and compared to the old $\mathrm{NO}_{x}$-based system. The comparison is based on revealed preferences of the involved vessel operators. Vessel specific data about the discounts and scores are analysed as well as the regional distribution of discounts and impacts on different vessel types. The paper shows that the Swedish Maritime Administration has succeeded in creating a system that attracts more vessel types and encompasses more environmental categories, but that the incentives to reduce $\mathrm{NO}_{x}$ emissions have been reduced. Ex-post cost-benefit analyses of the earlier certificate-based systems have proven them beneficial to society. However, it is unclear how the outcome of the new system will be. The paper suggests that there are efficiency gains in harmonising the system SMA has introduced with the different systems for environmentally differentiated port fees in Sweden.
\end{abstract}

Keywords: Cost-benefit analysis, Shipping, Environmental impact, NOx emissions

\section{Introduction}

The growing concern of society for reducing air emissions from shipping has resulted in the implementation of policy instruments targeting the reduction of these emissions from inter-governmental organisations, as the International Maritime Organization (IMO) and the European Union (EU), as well as national and local institutions. These policies have become an issue of significant concern, as the air emissions of sulphur oxides $\left(\mathrm{SO}_{\mathrm{X}}\right)$, nitrogen oxides $\left(\mathrm{NO}_{\mathrm{X}}\right)$ and particulate matter $(\mathrm{PM})$ represent negative

(c) The Author(s). 2020 Open Access This article is licensed under a Creative Commons Attribution 4.0 International License, which permits use, sharing, adaptation, distribution and reproduction in any medium or format, as long as you give appropriate credit to the original author(s) and the source, provide a link to the Creative Commons licence, and indicate if changes were made. The images or other third party material in this article are included in the article's Creative Commons licence, unless indicated otherwise in a credit line to the material. If material is not included in the article's Creative Commons licence and your intended use is not permitted by statutory regulation or exceeds the permitted use, you will need to obtain permission directly from the copyright holder. To view a copy of this licence, visit http://creativecommons.org/licenses/by/4.0/. 
externalities that have impacts on human health. At the same time, greenhouse gases (GHG) contribute to climate change.

The IMO has set a target to reduce GHG emissions from international shipping by at least $50 \%$ by 2050, as compared to the 2008 level (IMO 2018a). Due to EUagreements, the GHG-emissions, that are not part of the European trading system (EU-ETS), shall be reduced by $55 \%$ by 2030 compared to 1990 (European Commission 2020). Supporting this goal, Sweden aims to reduce the GHG emissions caused by domestic transport (excluding air transport) by 70\% between 2010 and 2030 and to reduce GHG emissions from all sectors to net-zero by 2045 (The Swedish Government 2016), which means that the Swedish climate goals are more ambitious than international targets. Besides, Sweden has set up nonquantified environmental goals regarding clean air, natural acidification only, and zero eutrophication that require a reduction of $\mathrm{SO}_{\mathrm{X}}, \mathrm{NO}_{\mathrm{X}}$, and $\mathrm{PM}$ emissions from the shipping industry.

The IMO has set energy efficiency standards to reduce the GHG emissions from international shipping via improved ship design (EEDI = Energy Efficiency Design Index) and operations (EEOI = Energy Efficiency Operational Indicator) (IMO 2019). Both the IMO (2018b) and the EU regulation 2015/757 (European Parliament and the Council 2015) have introduced monitoring systems for GHG emissions, fuel consumption, distance travelled, and transport work performed by ships. The collected data is planned to be used as a basis for future international agreements about global measures to reduce the GHG emissions from shipping. According to the EnviSuM project, that comprises partners from Finland, Norway, Denmark, Germany, Austria, Poland, Russia, and Sweden, IMO's EEDI alone will not be sufficient as a tool to meet GHG reduction targets in the Baltic Sea area. Furthermore, IMO's energy efficiency standards do not comply with domestic shipping (EnviSuM, 2019).

Over time, the IMO has tightened the $\mathrm{SO}_{\mathrm{X}}$ emission limits; these are, since 2015, $0.1 \%$ within the North American Sulphur Emission Control Area (SECA) and North European SECA, comprising the Baltic Sea, the North Sea and the English Channel, and since 2020, 0.5\% outside the SECAs. The $\mathrm{NO}_{\mathrm{X}}$ regulations are based on three emission reduction levels, Tier I to III, which become stricter over time and apply to new ships. Since 2016, Tier III is mandatory in the North American Nitrogen Emission Control Area (NECA) and from 2021 onwards, it will be mandatory in the North European NECA. This implies that IMO and EU requirements regarding the $\mathrm{SO}_{\mathrm{X}}$ and $\mathrm{NOx}$ emissions in the waters around Sweden are high compared to those in other parts of the world.

At the port level, all major Swedish ports apply environmentally differentiated port fees to fulfil local environmental programs and encourage shipping to go beyond legal requirements (von Bahr et al., 2018). Christodoulou et al. (2019) suggest that ports fees account for $47 \%$ of all policy instruments and measures related to air emissions from shipping implemented across the world. A high share of the instruments is applied in Europe and within Europe; the ports in the Baltic Sea region are particularly pro-active in environmental initiatives (COGEA, 2017). The International Association of Ports and Harbors (IAPH) has implemented a comprehensive World Ports Sustainability Program (WPSP 2020). It is now engaged with the IMO to enhance the role of ports as regards decarbonisation of shipping. 
In addition to the policy instruments and measures at the international and port level, Sweden applies environmentally differentiated fairway dues at the national level. The Swedish system for determining fairway dues at the national level is acknowledged as being unique in the world by considering the environmental performance of vessels (Haglind, 2008; Saharuddin et al., 2011). In contrast to the environmentally differentiated port fees, the national environmentally differentiated fairway dues are the same for all shipping companies and cannot be negotiated. The fairway dues supplement IMO and EU standards regarding energy efficiency, $\mathrm{SO}_{\mathrm{X}}$ and $\mathrm{NO}_{\mathrm{X}}$ emissions and ports' environmental policies.

\section{The Swedish maritime administration}

The Swedish Maritime Administration (SMA) is responsible for developing policies that support government goals. The primary duties of the SMA are maintaining the fairways, providing pilotage, icebreaking and maritime rescue services and acting to minimise the impact of shipping on the environment. The SMA is responsible for determining and collecting fairway dues and pilot fees. The revenue raised from the fairway dues is the largest source of income for the SMA. As the ports in Sweden and other countries, the SMA is limited to implementing a type of bonus-malus scheme. For the ports, this is due to the competition between the ports, for the SMA due to the competition from the land-based modes. Historically, the Swedish fairway dues consist of two parts; the cargo/passenger part calculated based on the cargo/passengers loaded or unloaded and the vessel part based on the size and characteristics of the vessel. Here, we address the later that is environmentally differentiated since 1998.

\section{Environmentally differentiated fairway dues}

A system based on certificates 1998-2017

In 1996 the SMA, the Swedish Shipowners Association (SSA) and the Swedish Ports and Stevedores Association (SPSA) reached a tripartite agreement to reduce the air pollution from sea transport. Between 1998 and 2014, $\mathrm{SO}_{\mathrm{X}}$ discounts were given based on certificates issued by the SMA, that confirmed the use of low sulphur fuel. The requirements became stricter over time (see Table 1).

The implementation of IMO's sulphur directive in 2015, with stricter requirements within the North European SECA, made the differentiation of fairway dues based on $\mathrm{SO}_{\mathrm{X}}$ emissions redundant. Comparing the 2014 and $2016 \mathrm{SO}_{\mathrm{X}}$ emission levels, EnviSuM (2019) calculated that the sulphur directive led to an $87 \%$ reduction of the $\mathrm{SO}_{\mathrm{X}}$ emissions and a 36\% reduction of the PM emissions in the Baltic Sea. During the same period, $\mathrm{CO}_{2}, \mathrm{NO}_{\mathrm{X}}, \mathrm{CO}$, Non-methane volatile organic compounds (NMVOC) emissions increased (see Table 2). PM emissions did not reduce as much as $\mathrm{SO}_{\mathrm{X}}$ emissions because PM consist of various chemical species that do not contain sulphur. A further reduction of $\mathrm{PM}$ emissions can be achieved via a reduction of $\mathrm{NO}_{\mathrm{X}}$ emissions. According to Brynolf (2014), the shift from heavy fuel oil (HFO) to marine gas oil (MGO) implies an over $90 \%$ decrease of the $\mathrm{SO}_{\mathrm{X}}$ emissions and an about $90 \%$ decrease of the PM emissions if the tank to propeller perspective is applied. The use of selective catalytic reduction (SCR) does not reduce the NOx emissions in general but reduces the emissions of secondary PM. EnviSuM (2019) calculated yearly benefits of at least $€ 670$ million related to health and $€ 109$ million related to the environment while the additional 
Table 1 Limits and discounts for the fairway dues 1997-2017

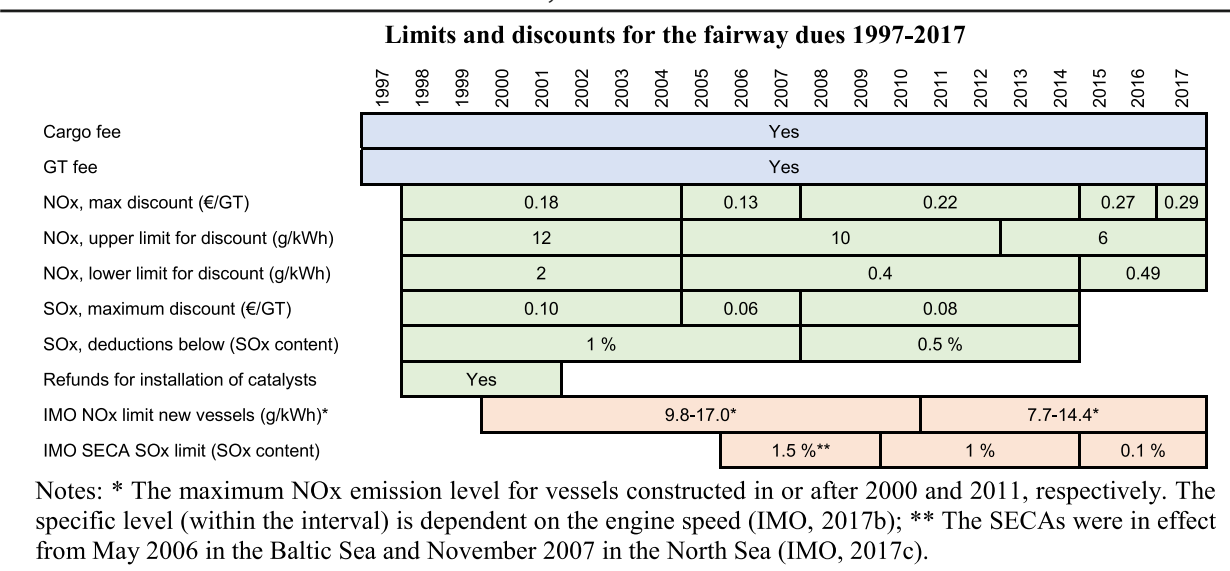

Source: Lindé et al. (2019)

${ }^{a}$ The maximum NOx emission level for vessels constructed in or after 2000 and 2011, respectively. The specific level (within the interval) is dependent on the engine speed (IMO 2017b)

${ }^{\mathrm{b}}$ The SECAs are in effect from May 2006 in the Baltic Sea and November 2007 in the North Sea (IMO 2017). Source: Lindé et al. (2019)

costs are calculated to be $€ 124$ million for the vessel operators and $€ 0.260$ million for the maritime authorities. Hence, the benefit was more than six times higher than the cost. For 2030, and in the presence of a business as usual alternative (BAU), all emissions are assumed to decrease.

Between 1998 and 2017, $\mathrm{NO}_{\mathrm{X}}$ discounts were given based on certificates issued by the SMA confirming the installation of purification techniques. The discount was given based on the level of $\mathrm{NO}_{\mathrm{X}}$ emissions (see Table 1). Between 1998 and 2001, refunds for the installation of catalysts were given on top of the NOx discounts. Lindé et al. (2019) found that the benefit for the society of reducing both $\mathrm{SO}_{\mathrm{X}}$ and $\mathrm{NOx}$ emissions has exceeded the cost. However, for many vessel operators reducing these emissions has not been economically profitable. SMA's environmental discounts covered, for instance, about $30 \%$ of the abatement cost to reduce NOx emissions. This figure must be seen in the light of the fact that most of the vessels that received $\mathrm{NO}_{\mathrm{X}}$ discounts were Ro-Pax-ferries and RoRoferries with frequent calls in Swedish ports (See section 4.1 for details). For the other vessel categories, a lower share of the costs is covered by the discount.

\section{A system based on the clean shipping index since 2018}

In 2016, the Swedish government commissioned the SMA to develop a new model for the fairway dues and the pilot fees (SMA, 2015). The goal was twofold: a) to develop a financial model that ensured a balanced economy, and b) to develop proposals for policy instruments that target more of shipping's environmental and health impacts than NOx (SMA, 2015).

Most regulations as of today are related to calls in ports. Sweden has reduced the tax for the electricity that vessels over 400 GT consume in ports (Skatteverket, 2019) and 2016, the Baltic Sea ports of Stockholm, Helsinki, Turku and Tallinn agreed on a public/ private funding of electrical connections in ports. About 20 Swedish ports apply environmentally differentiated port fees; two ports give incentives for the use of onshore power supply and four ports for the use of LNG. The ports of Goteborg and Gävle apply both 
Table 2 Emissions from Baltic Sea vessels (excl. IWW) in tonnes

\begin{tabular}{lllllll}
\hline Year & $\mathbf{C O}_{\mathbf{2}}$ (million) & $\mathbf{N O}_{\mathbf{x}}$ & $\mathbf{S O}_{\mathbf{x}}$ & $\mathbf{C O}$ & NMVOC & PM 2.5 \\
\hline 2014 & 14.4 & 31,400 & 7510 & 2110 & 256 & 1500 \\
2016 & 15.0 & 32,300 & 998 & 2210 & 267 & 962 \\
$2030(\mathrm{BAU})^{\mathrm{a}}$ & 12.7 & 17,100 & 845 & 1820 & 229 & 828 \\
\hline
\end{tabular}

${ }^{a}$ incl. Efficiency gains as described in Kalli et al. (2013), fleet and vessel growth rates as well as already agreed regulations to reduce NOx emissions that will be applied from 2021 onwards in the NECA

Source: EnviSuM (2019)

the Clean Shipping Index (CSI, 2019) and the Environmental Shipping Index (ESI, 2019), (see Table 3). There are no policy instruments that give incentives to reduce the environmental impacts from noise, emissions to water, e.g. due to the emissions of wash-water caused by the use of open-loop (or hybrid) scrubbers, including the handling of chemicals and waste, erosion and habitat and biodiversity losses. A GHG emission trading system, comparable to that for air transport, does not exist for sea transport.

The fairway dues system that was implemented on 1st January 2018 increased the importance of the vessel part at the expense of the cargo/passenger part. The importance of the cargo/passenger part, which depends to a greater extent on the economic situation and transport demand, was reduced to ensure more stable revenues for the SMA. The SMA's revenue related to the vessel part had been relatively stable until the new fairway system was implemented in 2018; it totalled $€ 57.7$ million in 2017 and increased to $€ 75.7$ million 2018 (SMA, 2019). The introduction of a readiness fee for

Table 3 Bases for environmental discounts in Swedish ports 2018

\begin{tabular}{|c|c|c|c|c|c|}
\hline Port & CSI & ESI & $\begin{array}{l}\text { Low NOx } \\
\text { emissions }\end{array}$ & LNG usage & $\begin{array}{l}\text { Onshore Power } \\
\text { Supply usage }\end{array}$ \\
\hline Brofjorden & $x$ & & & & \\
\hline Göteborg & $x$ & $x$ & & $x$ & \\
\hline Gävle & $x$ & $x$ & & & \\
\hline Sundsvall & & $x$ & & $x$ & \\
\hline Stockholm & $x$ & & $x$ & $x$ & $x$ \\
\hline Ystad & & & $x$ & $x$ & $x$ \\
\hline Falkenberg & & & $x$ & & \\
\hline Hargshamn & & & $x$ & & \\
\hline Helsingborg & & & $x$ & & \\
\hline Luleå & & & $x$ & & \\
\hline Norrköping & & & $x$ & & \\
\hline Petro Port (Stenungsund) & $x$ & & & & \\
\hline Piteå & & & $x$ & & \\
\hline Skellefteå & & & $x$ & & \\
\hline Södertälje & & & $x$ & & \\
\hline Sölvesborg & & & $x$ & & \\
\hline Uddevalla & & & $x$ & & \\
\hline Wallhamn & & & $x$ & & \\
\hline Åhus & & & $x$ & & \\
\hline Ports in Mälaren & & & $x$ & & \\
\hline Ports in Vänern & & & $x$ & & \\
\hline
\end{tabular}

Source: von Bahr et al. (2018) and CSI (2020) 
piloting explains a significant part of the increase (i.e. $€ 18$ million) (Carlsson, 2019). The SMA's revenue from the cargo/passenger part decreased as planned; it was reduced from $€ 49.8$ million (2017) to $€ 41.7$ million (2018). Furthermore, the new fairway dues system expresses the vessels' size in terms of net tonnage (NT) instead of gross tonnage (GT). The reduction of the fairway dues in specific ports and for specific vessel types was reduced or removed. The number of calls the vessel operators have to pay for per month is higher in the new system (five calls per month compared to two), but the fee is reduced for the last three calls $(75 \%, 50 \%, 25 \%)$.

The environmental differentiation of the new system is based on the Clean Shipping Index (CSI, 2019) that comprises the five categories: $\mathrm{NOx}$ emissions, $\mathrm{CO}_{2}$ emissions, $\mathrm{SO}_{\mathrm{X}}$ and $\mathrm{PM}$ emissions, handling of chemicals and handling of waste. A maximum of 30 points can be achieved per category for a maximum score of 150 . Table 4 reveals the share of the vessel part of the fairway dues that must be paid given the total score. Based on the total scores, the SMA divides vessels within the system into five classes, A to $\mathrm{E}$. The design of the system implies that it can be of interest to register a vessel without undertaking any measures, just to get a $10 \%$ reduction of the vessel part of the fairway dues.

According to SMA (2015), the CSI-based fairway dues system is expected to reduce shipping's total environmental impact at an increasing rate. In an ex-ante evaluation, Transport Analysis (2017) concluded that the environmental differentiation in the CSIbased fairway dues system does not provide the conditions for achieving more substantial incentives and environmental benefits. Transport Analysis (2017) recommended implementing the suggested system, but to base the environmental differentiation mainly, or only, on the reduction of $\mathrm{NO}_{\mathrm{X}}$ emissions. Besides, the SSA stated that the CSI-based fairway dues system would have less of an impact on the environment than the former system (Ekberg 2019). Possible needs for an adjustment of the system, in about 2023, is being discussed (Carlsson 2019). Furthermore, an agreement similar to the mentioned tripartite agreement, with the SMA, the SSA and the SPSA, is being deliberated. This time including the government initiative 'Fossil free Sweden' (von Bahr et al. 2018).

\section{Objective of this paper}

The objective of this paper is to carry out a comparative analysis of two alternative systems for environmentally differentiated fairway dues in Sweden and to give input to develop further the system taking into account the revealed preferences of the involved vessel operators. The analysis comprises a compilation of the number and type of vessels that received environmental discounts, the type and size of discounts and the number of calls per port and chosen routes. The paper also includes a discussion of the environmental impact of the old and the new system, the costs carried by different

Table 4 CSI-classes and share of vessel part of fairway dues to be paid

\begin{tabular}{llllll}
\hline CSI Class & E & D & C & B & A \\
\hline CSI score & no CSI & $<75$ & $75-99$ & $100-124$ & $125-150$ \\
Share to be paid & 1 & 1 & 0.9 & 0.3 & 0.1 \\
\hline Source: CSI (2019) & & & &
\end{tabular}

Source: CSI (2019) 
stakeholders, information available and information needed to evaluate the cost and benefit of the new system fully. It is assumed that the results will be useful for ports and national organisations that would like to go beyond the existing environmental regulations of the IMO and the EU.

Section 2 describes the approach that is applied and the data available to compare the two different fairway dues systems in Sweden. Section 3 summarises the objectives that have been set up and the impacts of the two systems. Section 4 analyses to what extent the objectives have been achieved in the different systems. Section 5 discusses general policy insights in an international context. Section 6 concludes and gives recommendations for the further development of the environmentally differentiated fairway dues and port fees.

\section{Method and data}

The comparative analysis of the two environmentally differentiated fairway dues systems is based on revealed preferences of the vessel operators. The SMA has provided vessel-specific data about the discounts and fairway dues paid per year during 19982019. The CSI organisation has provided information about the scores per CSIcategory in 2018 and 2019. Unfortunately, it has not been possible to get the main abatement measures undertaken (if any). Information on the number of calls per port and routes chosen is based on transport statistics and data from the Automatic Information System (AIS). Information about the administrative cost for the SMA and the vessels operators is taken from the SMA's impact analysis of the new fairway dues system (Ljungström 2016). Information about vessel operators' abatement costs and environmental impacts in physical terms is taken from Kågeson (1999) and Swahn (2002). Monetary valuations of non-priced effects are taken from the Swedish valuation guidelines (Swedish Transport Administration 2016) and the European Handbook on External Costs (Ricardo 2014).

\section{Objectives and overall impacts of fairway dues systems}

\section{A system based on $\mathrm{NO}_{x}$ and $\mathrm{SO}_{x}$ certificates}

In 1996, the SMA, the SSA and the SPSA set a target to decrease the $\mathrm{SO}_{\mathrm{X}}$ and $\mathrm{NO}_{\mathrm{X}}$ emissions from vessels that call at Swedish ports by $75 \%$ within 5 years (SMA 2000); however, this objective was not reached. The $\mathrm{SO}_{\mathrm{X}}$ emissions from vessels with certificates were estimated to have been reduced by about 50,000 t per year (SMA 2005); this figure can be compared to $1722 \mathrm{t} \mathrm{SO}_{\mathrm{X}}$ emissions from domestic sea transports and 39, $297 \mathrm{t} \mathrm{SO}_{\mathrm{X}}$ emissions from international sea transports on Swedish territory in 2014, the last year of SMA's $\mathrm{SO}_{\mathrm{X}}$-certificates (SCB 2020).

According to the Swedish valuation guidelines (Swedish Transport Administration 2016), the benefit for society from the reduced amounts of $\mathrm{SO}_{\mathrm{X}}$ emissions is calculated to be about $€ 0.145$ million per year. With the European unit values (Ricardo 2014) for the Baltic Sea (North Sea), the benefit would be $€ 0.236$ million ( $€ 0.342$ million). With an assumed unit cost of $€$ 0.4-1.08 per kg for reducing $\mathrm{SO}_{\mathrm{X}}$ emissions (Kågeson 1999; Swahn 2002), the costs for reducing the $\mathrm{SO}_{\mathrm{X}}$ emissions by $50,000 \mathrm{t}$ would be in the range of $€ 20$ to 54 million. Since the estimated reductions of $\mathrm{SO}_{\mathrm{X}}$ emissions appear somewhat uncertain, the absolute net benefit cannot be evaluated. However, the broad 
ratio of benefits to costs indicates that benefits for society by far exceed the costs; depending on which valuations and estimations of costs are used, the benefits to society of reducing the $\mathrm{SO}_{\mathrm{X}}$ emissions from ships would be about 3-17 times larger than the costs (Lindé et al. 2019).

Lindé et al. (2019) estimated that the reduced $\mathrm{NO}_{\mathrm{X}}$ emissions from certified vessels have been in the range 11,000 to 17,000 t per year in the Baltic Sea, Skagerrak, and Kattegat during the period 2003-2016. This figure can be compared to $9375 \mathrm{t}$ $\mathrm{NO}_{\mathrm{x}}$ emissions from domestic sea transports and 114,642t $\mathrm{NO}_{\mathrm{x}}$ emissions from international sea transports in 2016 (SCB 2020). Based on Kågeson (1999), SMA (2009), and Transport Analysis (2017), the costs associated with reducing $\mathrm{NO}_{\mathrm{X}}$ emissions by installing SCR vary between $€ 0.25$ and 0.67 per $\mathrm{kg} \mathrm{NO}_{\mathrm{X}}$. In 2014, when the reduced emissions from vessels with $\mathrm{NO}_{\mathrm{X}}$ reduction certificates were estimated to be 12,200t (SMA 2016), a cost of $€ 0.67$ per $\mathrm{kg} \mathrm{NO}_{\mathrm{X}}$ would translate into a total cost of $€ 8.2$ million. The SMA's discount given to vessels with NOx reduction certificates amounted to around $€ 5.8$ million in 2014 (SMA 2015). With a valuation of $€ 4.23$ per $\mathrm{kg}$, according to Swedish Transport Administration (2016) the benefit to society of reducing $\mathrm{NO}_{\mathrm{X}}$ emissions by $12,200 \mathrm{t}$ would be $€$ 51.6 million. Using a valuation of $€ 5.36$ per $\mathrm{kg} \mathrm{NO}_{\mathrm{X}}$ in the Baltic and the North Sea, according to (Ricardo 2014) the corresponding figure is $€ 65.3$ million. Hence, the benefits for society of reducing $\mathrm{NO}_{\mathrm{X}}$ emissions are calculated to be over six times higher than the costs. Carlsson (2019) assumes that the $\mathrm{NO}_{\mathrm{X}}$ discounts and refunds during the period 1998-2017 have compensated the vessel operators that have invested in purification techniques. In contrast, Lindé et al. (2019) find, based on cost figures in the literature, that the costs are not covered even for ferries with relatively high environmental discounts.

Regarding the synergies with environmentally differentiated port fees, SMA (2015) stated that about ten out of 50 Swedish ports apply NOx-differentiated schemes, a number that by 2018 had increased to 20 (see Table 3). This indicates that the environmental differentiation of the fairway dues and port fees were at least partly harmonised. However, the ports that base their fees on the NOx-certificates issued by the SMA will not be able to use the system for long as the SMA stopped issuing $\mathrm{NO}_{\mathrm{X}}$-certificates (that apply for a maximum of 5 years) by 31st December 2017.

\section{A system based on clean shipping index}

In 2015, the SMA, the Swedish Transport Agency and the Swedish Environmental Institute (IVL) performed a qualitative analysis in order to determine which components are the most important to be addressed in the SMA's environmentally differentiated fairway dues system (SMA, 2015). Based on the assessment of the environmental impact of $\mathrm{NO}_{\mathrm{X}}$, $\mathrm{SO}_{\mathrm{X}}, \mathrm{PM}$, methane, NMVOC, noise, as well as dangerous substances onboard, greywater and blackwater and the administrative cost of the SMA, the organisations agreed to focus on $\mathrm{NO}_{\mathrm{X}}, \mathrm{CO}_{2}$ and $\mathrm{PM}$ emissions as these have both significant environmental impacts and imply low administrative cost for the SMA (see Fig. 1).

SMA (2015) indicates that it is profitable, both from the vessel operators and the whole society's perspective, to reduce the emissions of $\mathrm{NO}_{\mathrm{X}}, \mathrm{CO}_{2}$ and $\mathrm{PM}$ especially from vessels that often call Swedish ports. 


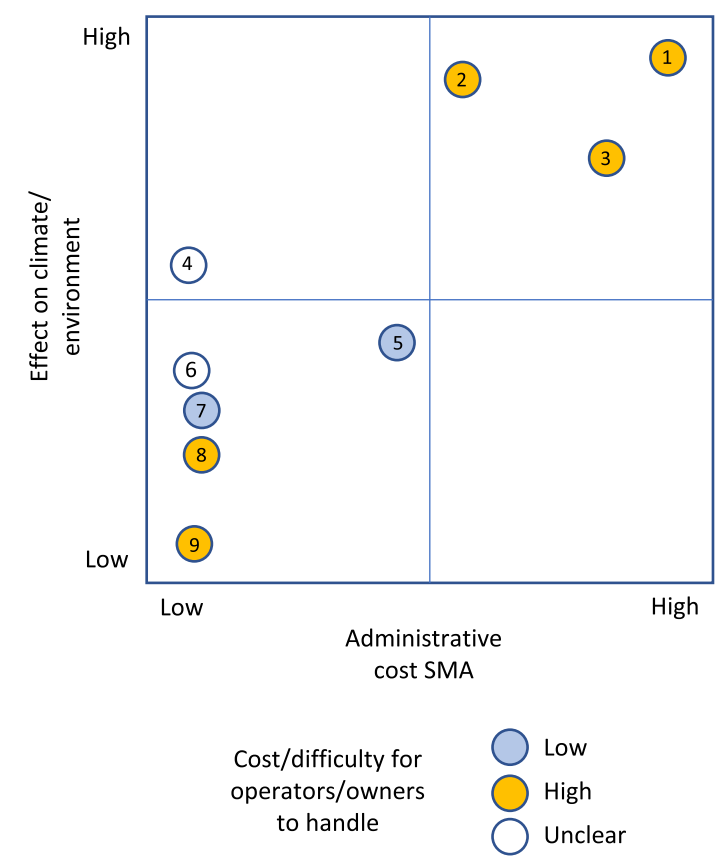

(1) NOx

(2) $\mathrm{CO} 2$

(3) Particals

(4) Methan

(5) Pollutants carried

(6) NMVOC

(7) Greywater

(8) Noise

(9) Blackwater

Fig. 1 Effects of environmentally hazardous substances and SMA's cost. Source: SMA (2015)

As a next step, the SMA assessed several possible policy instruments, namely a) own revised certificate system, b) own environmental index, c) joining existing environmental index like the Clean Shipping Index (CSI) or the Environmental Ship Index (ESI), d) investment grant and environmentally differentiated fairway dues and e) environmental fund and environmentally differentiated fairway dues. Investment grants and environmental funds on their own were not considered as these policy instruments would not accrue vessel operators that had already undertaken measures or ordered new vessels. Based on their evaluation, the SMA decided to use an existing environmental index. A key argument behind this choice was that using an existing index would lower the administrative cost compared to using a revised system of certificates or manage an environmental index of their own. The SMA's public procurement of an environmental index that guarantees a third-party verification resulted in only one bid, from CSI, and that bid was accepted (Carlsson, 2019). In 2020, the CSI is also used by five Swedish ports (see Table 3) and the ports of Vancouver and Prince Rupert in Canada (Christodoulou, 2019).

To get a discount, vessel operators must register their vessels in the CSI's score system. The SMA's fairway dues system is synchronised with the CSI-system. The operators can update the CSI-scores with new information whenever needed; updates are considered the following month. The amount of $\mathrm{CO}_{2}, \mathrm{SO}_{\mathrm{X}}$ and $\mathrm{PM}$ emissions must be verified every year. Vessel operators pay an administrative fee of $€ 500$ to the CSI to receive a three-year licence (SMA, 2019). The scoring of the five CSI-categories is based on different principles: 1) $\mathrm{NO}_{\mathrm{X}}$ emissions on Tier levels, 2) $\mathrm{CO}_{2}$ emissions on efficiency compared to reference vessels, 3) $\mathrm{SO}_{\mathrm{X}}$ and $\mathrm{PM}$ emissions on the sulphur content in the fuel used or whether the exhaust gases are treated, 4) handling of chemicals and 5) handling of waste. Both 4) and 5) are based on the exceeding of legal compliance. Data is entered on a vessel by vessel basis (CSI, 2019). 
CLEANSHIP (2013) recommend basing environmentally differentiated port fees on $\mathrm{NO}_{\mathrm{X}}$ and PM emissions, noise, and chemicals. In addition to these categories, CSI includes $\mathrm{CO}_{2}$ and $\mathrm{SO}_{\mathrm{X}}$ emissions and the handling of the waste; however, it omits noise. Concerning NOx, CLEANSHIP (2013) referred to SMA's environmentally differentiated fairway dues, concerning PM, discounts for the use of shore-side electricity and fuels with low PM emissions are mentioned. Regarding the handling of chemicals, it is suggested to follow the CSI or the Blue Angel label to promote the use of techniques to minimise the leakage of chemicals and oil. CLEANSHIP (2013) also recommended to include noise as a category, both caused by vessels and cargo handling and mentions the use of shore-side electricity and improved vessel design as measures to reduce noise.

\section{Comparative analysis}

\section{Total environmental discounts}

According to SMA (2015), the CSI-based fairway dues system is expected to induce more vessel operators to perform less expensive abatement measures for smaller environmental discounts compared to the certificate-based system that was in place until 2017. According to the SMA's forecast, the CSI-based scheme will lead to environmental discounts of around $€ 6.7$ million for about 100 vessels compared to $€ 6.5$ million for 31 vessels in 2017. In 2018, the number of vessels with a discount totalled 65, and in 201994 (see Table 5). In 2019, the segment with the highest number of vessels receiving a discount was RoPax-ferries, passenger ferries and cruises (31 vessels).

Compared to the old system, the new system has attracted an increased number of RoRo-vessels (from 3 vessels in 2017 to 20 vessels in 2019) and tankers (from 4 vessels 2017 to 27 vessels 2019). Figure 2 shows that the environmental discounts were about $€ 3.5$ million 2018, which is about half of the NOx-discounts 2017. However, in 2019 the 94 vessels received $€ 5.8$ million in discounts.

\section{Vessels that received environmental discounts}

The total number of calls in Swedish ports increased from 76,058 in 2017 to 79,612 in 2019; most of the calls, about 70\%, were made by RoPax-ferries, passenger ferries and cruises (see Table 6). The share of calls made with a discount, in this category of vessels, was $74 \%$ (2019), by far the highest compared to the other categories. Table 6 also reveals that the introduction of the CSI-based system, in 2018, has led to a higher share

Table 5 Number of vessels that received environmental discount 2016 and 2018

\begin{tabular}{|c|c|c|c|c|c|c|c|c|}
\hline \multirow[b]{2}{*}{ Type of vessel } & \multicolumn{4}{|c|}{$\begin{array}{l}\text { Total number of unique vessels } \\
\text { making calls in Swedish ports }\end{array}$} & \multicolumn{4}{|c|}{$\begin{array}{l}\text { Number of vessels with } \\
\text { discount }\end{array}$} \\
\hline & 2016 & 2017 & 2018 & 2019 & 2016 & 2017 & 2018 & 2019 \\
\hline Dry bulk/General Cargo/Specialized vessels & 1399 & 1404 & 1404 & 1422 & 2 & 2 & 3 & 16 \\
\hline Ropax/Passenger ferry/Day cruise/Cruise & 147 & 151 & 164 & 172 & 22 & 22 & 26 & 31 \\
\hline Roro & 190 & 189 & 190 & 195 & 5 & 3 & 15 & 20 \\
\hline Tanker & 822 & 804 & 840 & 806 & 5 & 4 & 21 & 27 \\
\hline Container & 185 & 185 & 148 & 134 & 0 & 0 & 0 & 0 \\
\hline Total & 2743 & 2733 & 2746 & 2729 & 34 & 31 & 65 & 94 \\
\hline
\end{tabular}

Source: SMA 


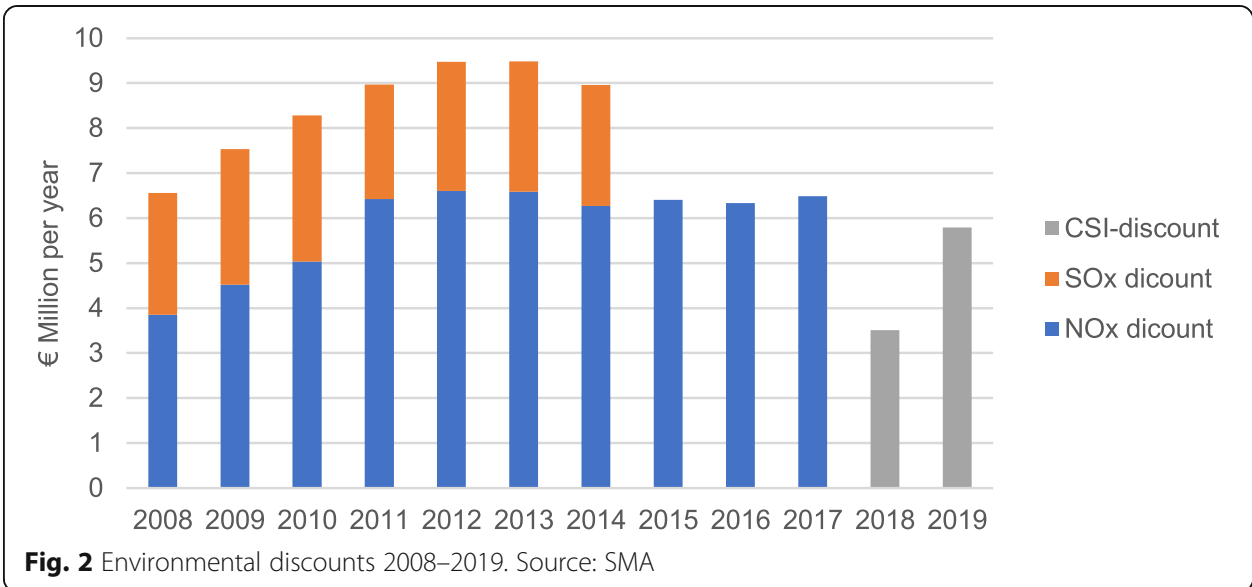

of calls with a discount for RoRo-vessels (from 3\% in 2017 to $41 \%$ in 2019) and tankers (from 1\% in 2017 to $11 \%$ in 2019). Owners of container vessels did not undertake any measures to receive discounts, neither in the NOx-certificate based system nor in the CSI-based system.

\section{Discounts related to RoPax}

The share of the calls 2016 by RoPax and passenger vessels with NOx-discount was highest on the Helsingborg-Helsingør line (89\%) and the two lines towards Visby/Gotland (86\%). About half of the calls related to the traffic between Sweden and Åland/Finland received discounts. Few or no discounts were registered for calls related to the traffic to/from Poland, Norway, Germany, and the Baltic states (see Fig. 3 and Table 7). In 2018, three additional vessels to Germany and two to Poland were registered in the CSI.

The CSI-based system has increased the number of RoPax and passenger vessels receiving discounts. However, most of the additional vessels received low scores on $\mathrm{NO}_{\mathrm{X}}$ emissions (which was the target in the $\mathrm{NO}_{\mathrm{X}}$ certificate system). The incentives to invest in purification techniques to reduce $\mathrm{NO}_{\mathrm{X}}$ emissions are most likely lower in the CSIbased system. This is due to the lower discounts in this system and the possibility to increase the total CSI score by addressing other categories in the CSI system, e.g. waste management, or $\mathrm{CO}_{2}$ emissions.

Table 6 Number of calls by vessel type and share with discount 2016, 2018 and 2019

\begin{tabular}{|c|c|c|c|c|c|c|c|c|}
\hline \multirow[b]{2}{*}{ Type of vessel } & \multicolumn{4}{|c|}{$\begin{array}{l}\text { Number of calls in Swedish } \\
\text { ports }\end{array}$} & \multicolumn{4}{|c|}{$\begin{array}{l}\text { Share of calls made by vessels } \\
\text { with discount (\%) }\end{array}$} \\
\hline & 2016 & 2017 & 2018 & 2019 & 2016 & 2017 & 2018 & 2019 \\
\hline Dry bulk/General Cargo/Specialized vessels & 10,766 & 11,164 & 12,254 & 13,039 & 0.4 & 0.4 & 0.1 & 1.6 \\
\hline Ropax/Passenger ferry/Day cruise/Cruise & 52,351 & 52,107 & 54,545 & 54,518 & 61.4 & 59.9 & 51.1 & 74.3 \\
\hline Roro & 2976 & 3089 & 3011 & 2745 & 2.7 & 2.0 & 36.6 & 40.9 \\
\hline Tanker & 7311 & 7383 & 7316 & 6942 & 1.4 & 1.2 & 7.6 & 11.1 \\
\hline Container & 2441 & 2315 & 2267 & 2368 & 0.0 & 0.0 & 0.0 & 0.0 \\
\hline Total & 75,845 & 76,058 & 79,393 & 79,612 & 42.7 & 41.3 & 37.2 & 53.5 \\
\hline
\end{tabular}

Source: SMA 


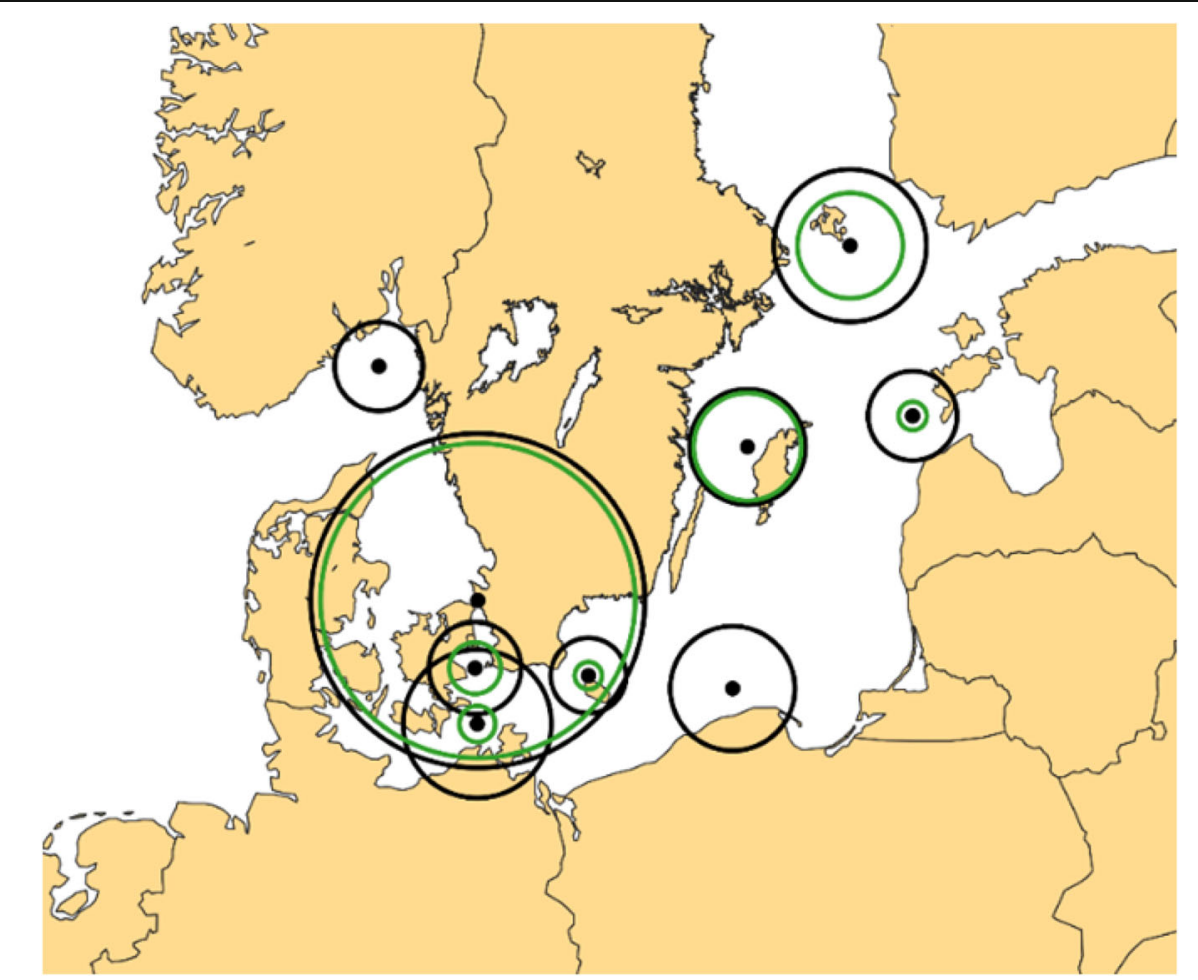

Fig. 3 Calls by ropax and passenger ferries 2016 by area of operation. Size of circles in proportion to number of calls (outer circle $=$ total calls, inner circle = calls with discount). Source: SMA and AIS, 2016

\section{Type of CSI-discounts}

In 2018, the total number of vessels with a CSI-score in SMA category A (see Table 4 for a description of the categories) was 10 (15.4\% of the vessels that received discounts), in category B 18 (27.7\%) and category C 37 (56.9\%). In 2019, the corresponding figures was 19 in category A (20.2\%), 32 in category B (34.0\%) and 43 in category C (45.7\%). The share of vessels in category A and B increased in 2019. Table 8 reveals large differences between the five CSI-categories. In both 2018 and 2019, more than $60 \%$ of the vessels receiving discounts, had a score of at least 26 in the ' $\mathrm{CO}_{2}$ ' category. The share of vessels with a high score in the category 'Waste' increased from $87 \%$ in 2018 to $91 \%$ in 2019. A high share of the black and grey water pollution is caused by passenger-,

Table 7 Total number of calls and calls with certificate by ropax and passenger ferries 2016 by area of operation

\begin{tabular}{llll}
\hline To/From & Total number of calls & Calls with certificate 2016 & Share (\%) \\
\hline The Baltic states & 2007 & 204 & 10.2 \\
Bornholm & 1445 & 189 & 13.1 \\
Helsingør (Denmark) & 28,286 & 25,054 & 88.6 \\
Norway & 1986 & 0 & 0.0 \\
Poland & 3933 & 0 & 0.0 \\
Germany & 5572 & 330 & 5.9 \\
The swedish island Gotland & 3402 & 2934 & 86.2 \\
Finland and the island Åland & 5904 & 2817 & 47.7 \\
Denmark (besides Helsingør) & 2154 & 671 & 31.2 \\
\hline
\end{tabular}


Table 8 Share of vessels with scores in different levels (\%) for each CSI category, end of 2018 and 2019

\begin{tabular}{|c|c|c|c|c|c|c|c|c|c|c|}
\hline \multirow[b]{2}{*}{ Score } & \multicolumn{2}{|l|}{$\mathrm{CO} 2$} & \multicolumn{2}{|c|}{ SOx_PM } & \multicolumn{2}{|l|}{ NOx } & \multicolumn{2}{|c|}{ Chemicals } & \multicolumn{2}{|l|}{ Waste } \\
\hline & 2018 & 2019 & 2018 & 2019 & 2018 & 2019 & 2018 & 2019 & 2018 & 2019 \\
\hline 0 & 0.0 & 0.0 & 6.3 & 6.4 & 4.8 & 4.3 & 0.0 & 0.0 & 0.0 & 0.0 \\
\hline $1-5$ & 7.9 & 8.5 & 6.3 & 7.4 & 7.9 & 7.4 & 0.0 & 0.0 & 0.0 & 0.0 \\
\hline $6-10$ & 1.6 & 3.2 & 20.6 & 12.8 & 15.9 & 20.2 & 11.1 & 6.4 & 0.0 & 0.0 \\
\hline $11-15$ & 3.2 & 3.2 & 23.8 & 24.5 & 6.3 & 5.3 & 52.4 & 46.8 & 0.0 & 0.0 \\
\hline $16-20$ & 4.8 & 3.2 & 15.9 & 19.1 & 14.3 & 9.6 & 28.6 & 33.0 & 1.6 & 0.0 \\
\hline $21-25$ & 20.6 & 18.1 & 15.9 & 11.7 & 12.7 & 16.0 & 7.9 & 6.4 & 11.1 & 8.5 \\
\hline $26-30$ & 61.9 & 63.8 & 11.1 & 18.1 & 38.1 & 37.2 & 0.0 & 7.4 & 87.3 & 91.5 \\
\hline All & 100.0 & 100.0 & 100.0 & 100.0 & 100.0 & 100.0 & 100.0 & 100.0 & 100.0 & 100.0 \\
\hline
\end{tabular}

RoPax- and cruise vessels in the Baltic Sea (Havsmiljöinstitutet 2014; Mellin and Creutzer 2014).

The numbers in Table 8 indicate that the room for improvements for the vessels currently in the system is limited in the categories ' $\mathrm{CO}_{2}$ ' and 'Waste'. There is, however, room for improvement in the categories 'Chemicals', 'SO $\mathrm{X}_{\mathrm{X}}$ and $\mathrm{PM}$ ' and NOx. Many of the vessels that entered the CSI system in 2018 scored high in the NOx category (a score between 26 and 30), held a NOx-certificate in the former system (18 out of 24 vessels). On the other hand, some of the vessels that entered the CSI system in 2018 and held a NOx certificate got a low total score (see Fig. 4). It is also evident that vessels can receive a high total score despite high NOx emissions; in 2018, 3 vessels and, in 2019, 4 vessels, received environmental discounts without a score in the 'NOx' category.

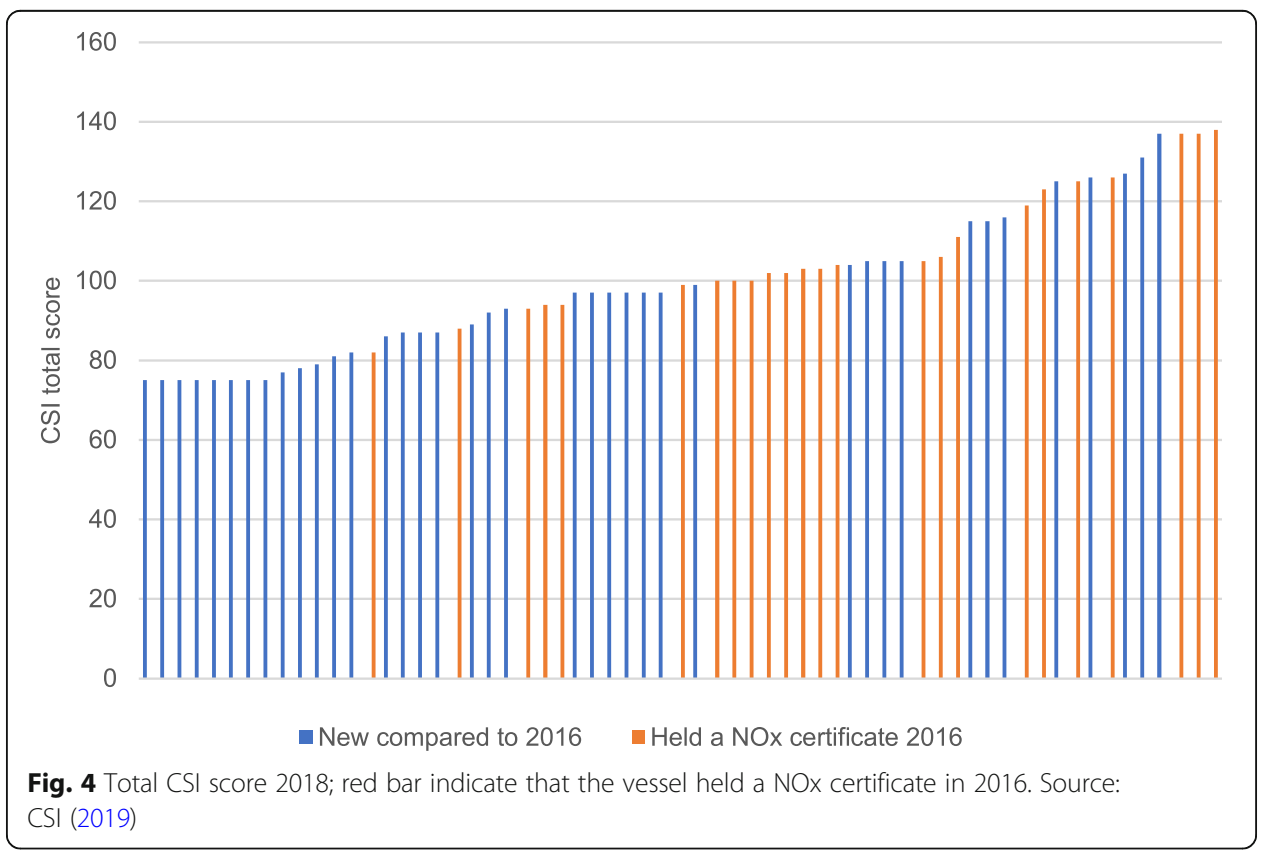




\section{Measures to receive higher scores}

Vessel operators need to perform specific abatement measures to receive CSI-scores in the five environmental categories:

1) NOx emissions: scores are based on IMO's emission levels Tier I $\left(\mathrm{NO}_{\mathrm{X}}\right.$ limit $17.0 \mathrm{~g} / \mathrm{kWh})$, Tier II $(14.4 \mathrm{~g} / \mathrm{kWh})$ and Tier III $(3.4 \mathrm{~g} / \mathrm{kWh})$. Two (extra) levels between Tier II and Tier III are included to reward different $\mathrm{NO}_{\mathrm{X}}$ reduction techniques.

2) $\mathrm{CO}_{2}$ emissions: scores are based on the vessels' energy efficiency compared to reference vessels of the same type and size calculated mainly using data published by the IMO. The efficiency is calculated in terms of $\mathrm{CO}_{2}$ emissions per tonne, TEU or passengers per nautical mile according to IMO's EEOI. The EEOI is not easy to apply as it is linked to operations that can change over time.

3) $\mathrm{SO}_{\mathrm{X}}$ and PM emissions: Scores are based on the sulphur content in the fuel, or whether the exhaust gases are treated. The fact that IMO's sulphur directive in 2015 reduced $\mathrm{SO}_{\mathrm{X}}$ emissions by $87 \%$ and PM emissions from Baltic vessels by $36 \%$, raises the question if it is appropriate to apply the same weight to the category $\mathrm{SO}_{\mathrm{X}}$ and $\mathrm{PM}$ emissions as for the $\mathrm{NO}_{\mathrm{X}}$ and $\mathrm{CO}_{2}$ emissions. This type of adjustments is discussed within the SMA (Carlsson, 2019).

4) Handling of chemicals: Scores are given to vessels that exceed legal compliance. However, there are indications that many illegal emissions of chemicals cause environmental impacts in the Baltic Sea which implies that there is no complete and detailed description of the emission of chemicals in the Baltic Sea (Havsmiljöinstitutet, 2014). The type and quality of the collection facilities in the ports and the willingness of municipalities to co-operate matter.

5) Handling of waste: Scores are given to vessels that exceed legal compliance. In this category, the access to and quality of the collection facilities in the ports is of importance.

Holmgren (2020) compiled vessel operators' abatement options and costs, (for example fuel switches, electrification, optimised propellers, slender hull, wind power, advanced route planning, slow steaming), for different vessel types and time frames related to the reduction of shipping's emissions to air and calculated how much the abatement options reduce the different emissions to air. Among the measures that specifically aim at reducing the $\mathrm{NO}_{\mathrm{X}}$ emissions, SCR is calculated to have the lowest cost, followed by the switch to LNG. In future scenarios with higher fuel costs for the conventional fuels (e.g. due to the inclusion of the shipping sector in the EU ETS) switches to renewable fuels and electrification are calculated to have lower costs. Many energy efficiency measures are calculated to have negative abatement costs for many of the vessel types and timeframes.

Regarding SMA's impact analysis, Ljungström (2016) assumed that the implementation of the CSI-based system would not lead to any additional administrative costs, neither for the vessel operators, apart from the registration of $€ 500$ that has to be paid for a year's' licence, nor for the SMA. Furthermore, it was assumed that the new fairway dues system would be easier to understand and more transparent than the former system. 


\section{Shift to land-based modes}

The CSI-based system and the higher fairway dues since 1st January 2018 have not led to a shift from sea to road in 2018 (Transport Analysis 2020), as feared by Transport Analysis (2017). EnviSuM (2019) found, based on statistical analysis for the period 2007-2017, that the cost increase caused by the sulphur directive, in 2015, did not result in a shift from sea to land transport for the total transport flows and the export flows; for imports such a modal shift could be seen.

\section{Organisational aspects}

CLEANSHIP (2013) studied 50 initiatives that assess vessels' environmental performance in ports in the Baltic region and concludes that high environmental ambitions are matched by the CSI and the Blue Angel label. CLEANSHIP (2013) also stated that the inclusion of more parameters in an index would likely increase the administrative cost but still recommended to include noise as an environmental category. So far, the results show that vessel operators find the new system harder to use than the old one. There is a trade-off between complexity and administrative cost.

The Swedish government also commissioned the SMA to analyse the possibilities to harmonise the SMA's environmentally differentiated fairway dues with the Swedish ports' environmentally differentiated port fees and other instruments (e.g. reduced national tax for electricity consumed in ports). There are potential synergies when both SMA's fairway dues and the ports' fees are based on the same environmental differentiation, see, e.g. von Bahr et al. (2018). However, the CSI is, as mentioned above, so far only used in five Swedish ports. In theory, it would be advantageous for vessel operators to be able to use the same system in ports all over the world or at least in Europe.

One question that arises is how the responsibility for environmental policy instruments should be distributed between the SMA and the ports. In other words, if it is more effective that ports and the SMA give discounts for the same environmental categories or if it is more effective that the SMA focuses on impacts at sea and the ports on the impacts at berth.

\section{General policy insights}

Sweden and other North European countries have set up ambitious environmental goals that exceed the targets of the IMO and the EU. Therefore, the fulfilment of these goals requires policy instruments and measures that go beyond the existing global and European regulations. The inclusion of the shipping sector in the European Emissions Trading System for GHG emissions, a similar global system or global fuels taxes would, of course, change the situation.

The implementation of the North European SECA in 2015 was profitable for society and it led to a considerable reduction of $\mathrm{SO}_{\mathrm{X}}$-emissions in the Baltic Sea, the North Sea, and the English Channel. This is also true for the SMA's environmentally differentiated fairway dues that were based on $\mathrm{SO}_{\mathrm{X}}$-certificates and contributed to a reduction of $\mathrm{SO}_{\mathrm{X}}$-emissions from vessels calling Swedish ports between 1998 and 2014.

The forthcoming implementation of the North European NECA in 2021 is expected to contribute to a reduction of $\mathrm{NO}_{\mathrm{X}}$ emissions, and move the shipping industry closer to achieving the Swedish environmental goals. The SMA's environmentally 
differentiated fairway dues that were based on $\mathrm{NO}_{\mathrm{X}}$ certificates, and contributed to the reduction of $\mathrm{NO}_{\mathrm{X}}$ emissions between 1998 and 2017, has been shown to be profitable for society but not for the vessel operators.

The $\mathrm{NO}_{\mathrm{X}}$ component of the CSI-based environmentally differentiated fairway dues system that has been in place since 2018 is an extra effort besides IMO's Tier requirements and the ports fees to reduce NOx emissions. It provides motivation for shipping companies to hasten their investment plans in vessels that satisfy the Tier III requirements in the North European NECA, requirements that must be met as of 2021. This is true even though the incentive to invest in purification techniques were most likely higher in the old $\mathrm{NO}_{\mathrm{X}}$ certificate-based system.

The objective to attract more vessel types and a higher number of vessels was achieved with the CSI-based system. However, over the 2 years studied, it is hard to identify the environmental impacts of the CSI system. A system drawback is the lack of a systematic collection and description of the abatement measures taken to receive higher scores. This makes quantitative evaluations difficult, if not impossible, and this is especially true as the vessel operators can undertake incremental improvements (not necessarily permanent) to achieve higher CSI-scores.

In Sweden, both the ports and the SMA are acting to minimise the impact of shipping on the environment. However, the ports are limited to implementing revenueneutral schemes, because of the pressures exerted by port competition (Wilmsmeier, 2012), and the SMA by the competition from road and rail transports.

Stronger incentives for change could be achieved by extending the use of environmental discounts to the whole Baltic Sea region. The Swedish Confederation of Transport Enterprises (Transportföretagen, 2013) suggests introducing environmentally differentiated port fees and incentives for all Baltic Sea ports in order to a) speed up the development and use of alternative marine fuels, b) make it possible for vessels to be connected to electrical outlets while lying in ports; and c) make it possible for ports to take grey and black water from the vessels. The question to be raised is if a fairway dues system, like in Sweden, should be introduced, and coordinated in a system that encompasses the whole Baltic Sea. In case of an affirmative answer, how should this coordination be carried out, both between agencies and ports in different countries?

\section{Conclusions}

In 2018, the SMA introduced a new system for levying fairway dues from vessels calling Swedish ports. The change was initiated by the Swedish government. The objective was to ensure a balanced economy for the SMA, that is mainly funded via user dues, but also to introduce a new way to give incentives for cleaner shipping. The earlier systems targeted air pollution caused by $\mathrm{SO}_{\mathrm{X}}$ and $\mathrm{NOx}$ emissions by giving discounts to vessels with emission levels below certain thresholds. In creating the new system, there was a demand for targeting more environmental categories like $\mathrm{CO}_{2}$ emissions, handling of chemicals and handling of waste. In working with the fairway dues system, the SMA has to consider the conflicting requirements of providing enough funding and working towards fulfilling environmental goals.

The environmentally differentiated fairway dues system is a national policy instrument that complements the international regulations of the IMO and EU, national tax regulations as well as local policy instruments in the ports. The system can be used to 
speed up the implementation of new technologies, induce fuel switches, use of more efficient operation and other actions that go further than existing regulations.

There is a demand for a short-term evaluation of the new environmentally differentiated fairway dues system. This paper provides some early results after two years and an overview of the information that is available today. Furthermore, the paper draws conclusions from the experiences gained from the fairway dues system that was implemented in 1998. The earlier system was based on NOx and SOx certificates issues by the SMA. One aim has been to map out the data available and what is missing for a complete cost-benefit analysis (CBA). The results can also be used to identify ways to improve the new system. For example, the paper has shown that when outsourcing the administration, the SMA must require the information necessary to evaluate the system.

One of the objectives of the CSI-based fairway dues was to include more environmental categories than $\mathrm{SO}_{\mathrm{X}}$ and $\mathrm{NO}_{\mathrm{X}}$ emissions. This objective was reached. Additional categories with the CSI-based fairway dues system are $\mathrm{CO}_{2}$ emissions, the handling of chemicals and the handling of waste. Furthermore, PM emissions are included as part of the $\mathrm{SO}_{\mathrm{X}}$-category.

One of SMA's objectives was for the new system to attract more vessels. A target was set at 100 vessels, and this was almost achieved in 2019. The earlier system only attracted around 30 vessels, mainly ferries. The share of cargo vessels that received discount increased from 29\% (2017) to 67\% (2019). The number of vessels receiving discounts is, however, no indicator for the environmental impact of the new system. It is also evident that it takes time to introduce a new fairway dues system. It takes time for shipping companies to evaluate the new system and take measures to receive a discount.

One crucial question is if the environmental discounts that the vessel operators can receive are large enough to give incentives to undertake measures that go beyond the existing regulations. As of now, based on the information available, this is hard to say. However, the SMA discounts for reducing NOx emissions were about 8 times higher in the old certificate-based system. Also, we find that many of the vessels that held a NOx certificate scored low in the CSI-based system, which implies that many vessels got high scores in other categories than NOx. The CSI-based system is more ambitious in encompassing more environmental categories (and vessels), but the drawback is that the incentive per category (and vessel) is reduced as it is difficult for the SMA to raise the budget for discounts.

A related issue is the limited room for improvement in some of the new categories. More than $60 \%$ of the vessels receiving a discount in the category ' $\mathrm{CO}_{2}$ ', had a score of at least 26 out of 30 possible. For the category 'Waste', the share was around $90 \%$. However, since the SMA gives discounts in three discrete steps (90, 70 and 10\% discount) depending on total score, operators of vessels with a score close to a cut-off point will have a higher incentive to take measures to improve. In this case, an incremental improvement in the categories ' $\mathrm{CO}_{2}$ ' and 'Waste' can give a substantial increase in discounts received. This can lead to actions from the shipping operators that are sub-optimal in reducing the environmental impacts.

Ideally, CBA should be applied to study the societal benefits in terms of reduced environmental impacts and the costs taken by vessel operators, ports, and maritime agencies. This should be done before and after the implementation of a new fairway dues 
schemes or any other policy instruments. The results of the ex-post CBA of the sulphur directive in the Baltic Sea region indicate that the benefits for society were more than six times higher than the costs. The benefit/cost ratio for the environmentally differentiated fairways dues based on $\mathrm{SO}_{\mathrm{X}}$ and $\mathrm{NO}_{\mathrm{X}}$ certificates, has been calculated to be in the same range.

The three CBAs above are restricted to emissions of $\mathrm{CO}_{2}, \mathrm{NO}_{\mathrm{X}}, \mathrm{SO}_{\mathrm{X}}$, and $\mathrm{PM}$ to air; where information about the fuel consumption, emission factors, unit values and national or European guidelines can be applied. To fully evaluate the new system, there is a need to address the limited knowledge when it comes to other external effects of shipping, e.g. the handling of chemicals and waste. Regarding the valuation of emissions to water, Mellin and Creutzer (2014) find that most studies focus on large oil spills, caused by tank vessels. We see a need for method development and data collection for other external impacts from shipping than emissions to air. In evaluating lower PM emissions, when other vessels than ferries are targeted, the use of AIS tracking will be vital since it is essential to track where the emissions occur.

Another shortcoming is that the CSI-system, as of today, does not provide sufficiently good information on actions taken to improve the environmental score of a vessel. A mapping of the actions taken is crucial for determining the cost side of a CBA. It is also vital for the study to assess how strong the incentives are.

Parts of the added categories in the CSI, e.g. vessels' consumption of fuel or electricity while lying in berth and the handling of waste and chemicals, are related to actions taken in ports. Typically, to improve on this, both vessel operators and ports and/or municipalities need to undertake abatement measures. Therefore, we find that the system could be made more efficient if the different systems for environmentally differentiated port fees could be harmonised across ports and synchronised with the system SMA has introduced.

\section{Acknowledgements}

The authors would like to thank Sven Carlsson and Joachim Henriksson, Swedish Maritime Administration, and Jonas Solberg, Clean Shipping Index, for the provision of detailed information and feedback. The authors would also like to thank the Swedish Transport Administration and Sweden's innovation agency for their funding. The article process charges of this work is supported by China Merchants Energy Shipping.

\section{Authors' contributions}

The paper contributes to research in the field of environmental policies in the maritime sector as it is analyses the impact of two different systems of environmentally differentiated fairway dues based on shipping companies' revealed decisions. Inge Vierth and Magnus Johansson performed calculations and wrote the paper. The authors read and approved the final manuscript.

Funding

The paper was funded by the Swedish Transport Administration (Trafikverket) and Sweden's innovation agency (VINNOVA)

\section{Availability of data and materials}

The data material was delivered by the Swedish Maritime Administration and Clean Shipping Index and can be made available. 
Received: 2 January 2020 Accepted: 29 September 2020

Published online: 25 November 2020

\section{References}

Brynolf A (2014) Environmental assessment of present and future marine fuels, Thesis. Department of Shipping and Marine Technology, Chalmers University of Technology, Gothenburg

Carlsson S (2019) TF chef Strategisk analys \& utredning, Sjöfartsverket/Swedish maritime administration. (I. Vierth, Intervjuare)

Christodoulou, A. (2019). Maritime environmental performance indices: useful tools for the evaluation of the transport supplier environmental performance? Draft working paper

Christodoulou A, Gonzalez-Aregall M, Lindé T, Vierth I, Cullinane K (2019) Targeting the reduction of shipping emissions to air: a global review and taxonomy of policies, incentives and measures. Marit Bus Rev 16-30

CLEANSHIP (2013) CLEANSHIP - Clean Baltic Sea Shipping, Task 4.6 An analysis of environmentally differentiated ports dues. Ports of Stockholm and IVL

COGEA (2017) Study on differentiated port infrastructure charges to promote environmentally friendly maritime transport activities and sustainable transportation. Hämtat från MOVE/B3/2014-589/SI2.697889, European Commission, Brussels (Acce3ssed 2019-06-12): https://ec.europa.eu/transport/sites/transport/files/2017-06-differentiated-port-infrastructurecharges-report.pdf

CSI (2019) Hämtat från. https://www.cleanshippingindex.com/

CSI (2020). Benefits. https://www.cleanshippingindex.com/benefits/, Clean Shipping Index.

Ekberg H (2019) Avgifter höjs trots kritik. Sjöfartstidningen

EnviSuM (2019) Clean Shipping: Exploring the impact of emission regulation (Final report April 2019) . https://blogit.utu.fi/ envisum/: Interreg Baltic Sea Region

ESI (2019) Environmental ship index ESI. Hämtat från http://www.environmentalshipindex.org/Public/Home

European Commission (2020) 2030 Climate Target Plan. https://ec.europa.eu/clima/policies/eu-climate-action/2030_ctp_en, European Commission.

European Parliament and the Council (2015) On the monitoring, reporting and verification of carbon dioxide emissions from maritime transport, and amending Directive 2009/16/EC. Regulation (EU) 2015/757.

Haglind F (2008) A review on the use of gas and steam turbine combined cycles as prime movers for large ships. Part l: Background and design. Energ Conver Manage 49(12):3458-3467

Havsmiljöinstitutet (2014) Sjöfarten kring Sverige och dess påverkan på havsmiljön . Havsmiljöinstitutet (Havsmiljöinstitutets rapport 2014:4)

Holmgren, K. (2020). Emission reductions and costs of abatement measures for air pollutants and greenhouse gases from shipping - Selected measures with importance for the Swedish Environmental Quality Objectives. VTI notat 8a-2019, VTI.

IMO (2017) Special areas under MARPOL. http://www.imo.org/en/OurWork/Environment/SpecialAreasUnderMARPOL/Pages/ Default.aspx, IMO.

IMO (2018a) Initial IMO strategy on reduction of GHG emissions from ships. Resolution MEPC 304(72) IMO

IMO (2018b) Data collection system for fuel oil consumption of ships (MEPC.278(70)). http://www.imo.org/en/OurWork/ Environment/PollutionPrevention/AirPollution/Pages/DataCollection-System.aspx, IMO.

IMO (2019) Energy efficiency measures. http://www.imo.org/en/OurWork/Environment/PollutionPrevention/AirPollution/ Pages/Technical-and-Operational-Measures.aspx, IMO.

Kågeson P (1999) Economic instruments for reducing emissions from sea transport. Air Pollution and Climate Series No. 11, T\&E Report 99/7, The Swedish NGO Secretariat on Acid Rain, The European Federation for Transport and Environment (T\&E) and the European Environmental Bureau (EEB), Stockholm. https://www.transportenvironment.org/sites/te/files/ media/T\%26E\%2099-7_0.pdf. Accessed 25 Oct 2018

Kalli J, Jalkanan J-P, Johansson L, Repka S (2013) Atmospheric emissions of European SECA shipping: long term projections. WMU J Marit Aff 12:129-145

Lindé T, Vierth I, Cullinane K (2019) Evaluating the effects of Sweden's environmentally differentiated fairway dues. Transp Res D $70: 77-93$

Ljungström T (2016) Konsekvensutredning med anledning av nya föreskrifter för farledsavgift samt för tillhandahållande av lots, lotsbeställning, tilldelning av lots and lotsavgifter. Sjöfartsverket (PM 2016-03-07)

Mellin A, Creutzer C (2014) SJÖSAM - sjöfartens samhällsekonomiska marginalkostnader. VTI (VTI rapport 807/2014)

Ricardo (2014) Update of the handbook on external costs of transport (final report). Ricardo-AEA, London

Saharuddin AH, Sulaiman O, Nik WW (2011) Air emission from ship driving force for next generation marine technological and policy change: a review. Afr J Bus Manag 5(33):12664-12683

SCB (2020) Utsläpp av luftföroreningar. https:/www.scb.se/hitta-statistik/statistik-efter-amne/miljo/utslapp/utslapp-avluftfororeningar/, SCB.

Skatteverket. (2019). Lägre skatt på el som förbrukas i skepp. Hämtat från https://www.skatteverket.se/ foretagochorganisationer/skatter/punktskatter/energiskatter/verksamhetermedlagreskatt/skeppochbatar/ lagreskattpaelsomforbrukasiskepp.4.121 b82f011a74172e588000340.html

SMA (2000) Insatser inom området Agenda 21 och hållbar utveckling. Sjöfartsverket 2000-10-24.

SMA (2005) Sjöfartens utveckling 2004 - sektorrapport. https://www.sjofartsverket.se/upload/Listade-dokument/Rapporter_ Remisser/SV/2005/Sektorrapport\%202004.pdf, Sjöfartsverket.

SMA (2009) Handlingsplan för att reducera kväveoxiduts/äpp från fartyg. 2009-10-13 Sjöfartsverket.

SMA (2015) Sjöfartsverkets redovisning av regeringens uppdrag (N2015/5048/SUBT) om att ureda en finansiell modell. Sjöfartsverket, Norrköping

SMA (2019) Årsredovisning 2018 för Sjöfartsverket. Sjöfartsverket, Norrköping

Swahn H (2002) Environmentally differentiated fairway charges in practice - the Swedish experience. Swedish Maritime Administration, Norrköping

Swedish Transport Administration (2016) Analysmetod och samhällsekonomiska kalkylvärden för transportsektorn: ASEK 6.1. https://www.trafikverket.se/ASEK/, Trafikverket.

The Swedish Government (2016) En Klimat- och luftvårdsstrategi för Sverige. SOU 2016:47, Regeringen. 
Transport Analysis (2017) Miljökonsekvenser av nya farledsavgifter (PM 2017:9)

Transport Analysis (2020) Transportarbete. https://www.trafa.se/ovrig/transportarbete/, Trafikanalys.

Transportföretagen (2013) Hämtat från https://www.transportforetagen.se/Nyheter/2013/Slutrapport-fran-Cleanship\%2D\%2 DClean-Baltic-Sea-Shipping

von Bahr J, Romson Å, Sköld S, Winnes H (2018) Statlig styrning av hamnavgifter för fartyg. IVL (Nr C 370)

Wilmsmeier G (2012) Infrastructure charges: creating incentives to improve environmental performance. Bulletin FAL 309(5)

https://www.researchgate.net/publication/283407929_Infrastructure_charges_creating_incentives_to_improve_

environmental_performance: $1-7$

WPSP (2020) World ports sustainability report 2020. https://sustainableworldports.org/wp-content/uploads/WORLD-PORTSSUSTAINABILITY-REPORT-2020-FIN.pdf

\section{Publisher's Note}

Springer Nature remains neutral with regard to jurisdictional claims in published maps and institutional affiliations.

Submit your manuscript to a SpringerOpen ${ }^{\odot}$ journal and benefit from:

- Convenient online submission

- Rigorous peer review

- Open access: articles freely available online

High visibility within the field

- Retaining the copyright to your article

Submit your next manuscript at $\boldsymbol{\nabla}$ springeropen.com 